\title{
Evaluation of hepatic fibrosis with noninvasive methods: transient elastography in HIV infected patients
}

\author{
Elena Dumea ${ }^{1,2^{*}}$, Simona Claudia Cambrea ${ }^{1,2}$, Maria Margareta $\|_{i e^{2}}$, Lucian Cristian Petcu ${ }^{1}$, Adrian Streinu-Cercel ${ }^{3}$ \\ From The 9th Edition of the Scientific Days of the National Institute for Infectious Diseases Prof Dr Matei Bals \\ Bucharest, Romania. 23-25 October 2013
}

\section{Background}

Measurement of liver stiffness using transient elastography is a noninvasive, reliable predictor of hepatic fibrosis, but data on its use in HIV infected patients are limited.

\section{Methods}

We evaluated 39 patients with HIV/AIDS infection, who were under monitoring at the HIV Day Clinic of the Clinical Hospital of Infectious Diseases Constanța. In these patients we evaluated liver fibrosis using FibroScan. Statistical analysis was performed with SPSS 17.0.

\section{Results}

The mean FibroScan score was $5.153 \mathrm{kPa}$, with a standard deviation (SD) of $1.493 \mathrm{kPa}$.

There were 19 patients with CD4 counts between 200500 cells $/ \mathrm{cmm}$; in this group, the mean value of FibroScan was $5.378 \pm 1.415 \mathrm{kPa}$. In the 20 patients with CD4 count above 500 cells $/ \mathrm{cmm}$, the mean FibroScan score was $4.94 \pm 1.56 \mathrm{kPa}$.

There were no statistically significant differences between groups regarding the CD4 count $(p=0.36)$. In this study we did not select cases of patients with severe immunodepression (CD4 count below 200 cells/cmm).

Regarding HIV viral load (VL), we split patients into two groups, above and below 400 copies $/ \mathrm{mL}$. There were 31 patients with VL less than 400 copies $/ \mathrm{mL}$; the mean FibroScan score was $5.161 \pm 1.633 \mathrm{kPa}$. There were 9 patients with VL more than 400 copies $/ \mathrm{mL}$, with a mean FibroScan score of $5.125 \pm 0.818 \mathrm{kPa}$. There were no statistically significant differences between groups regarding HIV VL ( $\mathrm{p}=0.931)$.

\footnotetext{
* Correspondence: elenadumea@yahoo.com

'Ovidius University, Constanța, Romania

Full list of author information is available at the end of the article
}

\section{Conclusion}

In the studied patients there were no significant differences in terms of liver fibrosis evaluated by FibroScan. We included no patients with severe immunodepression and all patients received combined antiretroviral therapy.

Noninvasive methods for the evaluation of liver fibrosis are less studied in HIV patients. Further extensive studies are necessary for such patients in order to evaluate cutoffs for assessing liver fibrosis and cirrhosis.

\section{Authors' details \\ ${ }^{1}$ Ovidius University, Constanța, Romania. ${ }^{2}$ Clinical Hospital of Infectious Diseases, Constanța, Romania. ${ }^{3}$ Carol Davila University of Medicine and Pharmacy, Bucharest, Romania.}

Published: 16 December 2013

doi:10.1186/1471-2334-13-S1-P19

Cite this article as: Dumea et al:: Evaluation of hepatic fibrosis with noninvasive methods: transient elastography in HIV infected patients. BMC Infectious Diseases 2013 13(Suppl 1):P19.

Submit your next manuscript to BioMed Central and take full advantage of:

- Convenient online submission

- Thorough peer review

- No space constraints or color figure charges

- Immediate publication on acceptance

- Inclusion in PubMed, CAS, Scopus and Google Scholar

- Research which is freely available for redistribution 